\title{
Inflation and Economic Growth Paradox: A Co-integration Analysis in Nepal
}

\section{Uttam Lal Joshi}

\author{
M. Phil. Scholar, Nepal Open University
}

Lecturer, Economics, Makawanpur Multiple Campus, Hetauda

Email: uttamjoshi88@gmail.com

DOI: https://doi.org/10.3126/irjmmc.v2i3.40055

Received: August 07, 2021; Revised \& Accepted: September 12, 2021; Published: September 29, 2021

(C) Copyright: Joshi (2021).

\section{ABSTRACT}

The empirical study investigates the relationship between economic growth, inflation and broad money supply in Nepal. Data since 1965 to 2020 are taken from World Bank and Autoregressive Distributive Lag Model is used to find cointegration between the variables to show long run and short run dynamics. Augmented Dickey-Fuller and Philips- Perron tests are conducted to find the unit roots in the model. Result shows the error correction term is negative (-0.75) and significant (0.0043) where bounds test supports the long run cointegration and error correction model suggest the speed of adjustment. The estimated regression equation is found robust and stable (serial correlation and heteroskedacity tests). The research shows inflation has short run and long run impact on economic growth so inflation should be kept within its threshold level from sound monetary and fiscal policy mechanism.

Keywords: Bounds Test, Broad Money Supply, Cointegration, GDP growth, Inflation,

\section{INTRODUCTION}

This paper examines the impact of inflation on economic growth in Nepalese context. Economic growth and inflation are major macroeconomic issues in developing countries. Data are taken from 1965 to 2020 to find the cointegration relationship to assess the impact of inflation on economic growth. Economic Growth is taken as dependent variable and inflation (CPI) and broad money supply are independent variables to find cointegration between them in the model. The author employs Autoregressive Distributive Lag Model to find the nexus between the variables after Augmented Dickey- Fuller and Phillips- Perron unit root tests. Literatures show the long run and short- run effect of inflation on economic growth where positive impact of inflation on economic growth is found within its threshold level but negative impact is seen when the rate is more than its border line that causes damaging the economy (Hossin, 1961).

Inflation is found highly correlated with economic growth to the degree that macroeconomic policy is focused on demand management as a stimulus to growth (Pollin et al., 2005). Various researches show the relationship between inflation and economic growth that remains controversial or inconclusive. Both negative and positive relationship can be 
found in several cases but it shows low and stable inflation promotes economic growth and vice versa (Ahmed, 2010). So Inflation should be kept within its threshold level for sound economic health of the country. Beyond that level of inflation rate, higher or lower than threshold value, the economic growth can be jeopardized (Bhusal et al., 2011). Inflation needs to be maintained at a reasonable level to boost economic growth in the country. If the rate is higher than its level the rate of growth goes down. It implies that the inflation should be kept within its border line from sound monetary and fiscal policy mechanism.

The purpose of the study is to find the impact of inflation on economic growth. The study applies the Autoregressive Distributive Lag Model to find the long- run and short- run dynamic relationship between GDP Growth, Inflation and Broad Money Supply. The result of the paper shows that inflation has short- run and long- run causation with GDP Growth Rate that implies monetary authority and the government should focus on the mechanisms to check inflation for economic growth of the country. The remainder of this paper is organized in the following ways: Section 2: Literature Review, Section 3: The Model and Methodology, Section 4 discusses the Result and in Section 5: Conclusions and Discussions are presented.

\section{LITERATURE REVIEW}

The relationship between economic growth and inflation are reviewed in various literatures and multiple relationships can be found in different situations using different methods to study. In most of the literatures OLS, ARDL, Johansen Cointegration and Granger Causality methods are applied to explain the relationship between economic growth and inflation where diversified mutual relationship can be specified.

In the study using ARDL Bounds test Adhikari (2015) states that economic growth of Nepal of current time is mostly affected by inflation and current economic growth is favorably affected by inflation of preceding time.

But inconclusive result is found by Karki et al. (2020) and states the study found the conducive and detrimental result explaining the threshold value of inflation in Nepal is 6 percent and after this rate of inflation is harmful to the country. It is necessary to keep inflation within its threshold level for the economic growth of the country. Using annual data for the period of 1960-2006 in Pakistan, Hussain et al. ( 2011) examines the relationship between inflation and economic growth and finds that inflation is positively related with economic growth and vice- versa. Inflation is causing growth but not vice- versa. They applied Error Correction Model to test whether an economy is converging towards equilibrium in the short- run or not.

In the research paper written by Jayathilake \& Rathnayake (2013) using cointegration and causality test after ADF and Phillps- Perron unit root tests shows there is negative relationship between inflation and economic growth in Sri Lanka. They used Johansen's Cointegration test and Bound test with Vector Error Correction Model and Granger Causality test in the study and found no significant relationship between the variables in China and India. The causality result shows there is a unidirectional causality that runs from economic growth to inflation in China.

Likewise the relationship between economic growth and inflation in Sri Lanka is explained by Madurapperuma (2016) and finds that there is long- run negative and significant 
relationship between inflation and economic growth that supports the model of utility function in consumption and real money balances. The study used Johansen Cointegration test and Error Correction Model for the period of 1988- 2015.

In the research study by Akinsola \& Odhiambo (2017) states reviewing the existing literatures that the impact of inflation on economic growth varies country to country over time. They find that the result depends on country- specific characteristics, data used and methodology employed. There is negative relationship found in the context of developed countries but there is still controversy about the threshold level of inflation desired for economic growth.

Studying the economy of Italy and Austria for the period of 1980 to 2016, Švigir et al. (2017) shows that the relationship between inflation and economic growth may be positive, negative and neutral. They find that low inflation is important but not sufficient for economic growth of the country.

Applying Autoregressive Distributive Lag Model on the selected variables in Nigeria, a research study by Adaramola et al.(2020) finds inflation and exchange rate have significant impact on economic growth whereas money supply shows the positive impact on it. Other variables in this study such as interest rate, degree of economy's openness and government consumption expenditure have no influence on economic growth. Using innovative threshold model and system GMM approach Khan \& Hanif (2020) states that above a minimum level of is institutional quality inflation- growth relationship is negative and below it is nonexistent. They used large panel of 113 economies over the period 1981-2015.

Studying the data from 100 countries, Barro (2013) found the impacts of an increase in inflation by 10 percent per year can cause to reduce the economic growth by $0.2-0.3$ percent per year. Statistically significant results emerge when high- inflation experiences are included and adverse effect of inflation on economic growth is small.

\section{MATERIAL AND METHOD}

The study uses the time series data from World Bank since 1965 to 2020 to find the relationship between GDP Growth, inflation and broad money supply. Autoregressive Distributive Lag Model is used after Augmented Dickey- Fuller and Phillips- Perron unit root test results.

\subsection{Model Specification}

The base model showing economic growth, inflation and broad money supply can be specified as:

$$
\mathrm{GRt}=\mathrm{f}(\mathrm{CPI}, \mathrm{M} 2 \mathrm{t})
$$

It can be expressed as:

$$
\mathrm{GRt}=\beta \mathrm{o}+\beta 1 \mathrm{CPIt}+\beta 2 \mathrm{M} 2 \mathrm{t}+\mathrm{e}
$$

Where, GR $=$ GDP Growth Rate, CPI $=$ Consumer Price Index showing Inflation and M2= Broad Money Growth in the country. $\beta$ o is constant term, $\mathrm{t}$ is time trend and e is error term in the model. 


\subsection{Unit Root Test}

Tests of unit root are estimated at the first step before estimating Autoregressive Distributive Lag Model. It determines whether the series have stationary property or not. Augmented Dickey- Fuller and Phillips- Perron tests are conducted for confirming the series are non- stationary for further test of cointegration. The tests are conducted with the following $\mathrm{ADF}$ and PP tests regressions.

$$
\begin{aligned}
& \Delta \mathrm{Yt}=\alpha_{0}+\delta \mathrm{t}+\alpha_{1} \mathrm{Yt}-1+\sum_{t=1}^{p} \alpha i \Delta Y t-1+\varepsilon_{1 \mathrm{t}} \\
& \Delta \mathrm{Yt}=\alpha_{0}+\delta \mathrm{t}+\alpha_{1} \mathrm{Yt}-1+\varepsilon_{1 \mathrm{t}}
\end{aligned}
$$

In the empirical study some variables are found stationary in $\mathrm{I}(0)$ order whereas other are found in I(1). Engel and Granger (1987), Johansen (1988) and Johansen et al. (1990) cointegration tests are used in the case of stationary in first difference and same order of all variables. Bounds test by Pesaran et al. (2001) removes this type of situation to find cointegration between the variables under the series $\mathrm{I}(0)$ and $\mathrm{I}(1)$.

\subsection{ARDL Model}

The Autoregressive Distributive Lag model by Pesaran et al. (2001) can be mentioned as follows:

$\Delta \mathrm{GRt}=\alpha_{0}+\sum_{i=1}^{p} \alpha 1 i \Delta G R t-1+\sum_{i=1}^{q} \alpha 2 i C P I t-1+\sum_{i=1}^{r} \alpha 3 i \Delta M 2 t-1+\mathrm{b}_{1} \mathrm{GRt}-$ $1+\mathrm{b}_{2} \mathrm{CPIt}-1+\mathrm{b}_{3} \mathrm{M} 2 \mathrm{t}-1+\varepsilon_{1 \mathrm{t}}$

Where, GR = GDP Growth Rate, CPI = Consumer Price Index, M2 = Broad Money Supply Bounds test in ARDL model determines the long run relationship that shows the contegration between the variables. The coefficients $\alpha_{0}, \alpha 1 \mathrm{i}, \alpha 2 \mathrm{i}$ and $\alpha 3 \mathrm{i}$ represent short run dynamics and $b_{1}, b_{2}$ and $b_{3}$ represent the long run dynamic relationship. F-statistics is used to test the null hypothesis Ho: $b_{1}=b_{2}=b_{3}=0$ stating that there is no co-integration among the variables in ARDL model against the alternative hypothesis $H 1: b_{1} \neq b_{2} \neq b_{3} \neq 0$ defining cointegration between them. If cointegration exists among the variables that signifies long run and short run coefficients are reliable.

\subsection{Error Correction Model}

The Error Correction Model is established if cointegration exists between the variables. The ECM model is:

$\Delta \mathrm{GRt}=\alpha_{01}+\sum_{i=1}^{p} \alpha 1 i G R t \quad 1+\sum_{i=1}^{q} \alpha 2 i C P I t \quad 1+\sum_{i=1}^{r} \alpha 3 i M 2 t-1+\lambda \mathrm{ECTt}-1+\varepsilon_{\mathrm{t}}(6)$

ECTt-1is error correction term and $\lambda$ is the coefficient that shows speed of adjustment to long run equilibrium.

\section{RESULT}

\subsection{Unit Root Test}

Unit root test is estimated to find the condition of stationary in the variables (GR, CPI and M2). Augmented Dickey-Fuller and Phillips- Perron tests are performed to find the existence of unit roots of each variable in the model. The result of ADF and PP tests are presented in the table 1. 
Table 1

Unit Root Test

\begin{tabular}{|c|c|c|c|c|}
\hline \multirow{2}{*}{ Variables } & \multicolumn{2}{|c|}{$\mathrm{ADF}$} & \multicolumn{2}{|c|}{ PP } \\
\hline & Level & First Difference & Level & First Difference \\
\hline GR & $-5.925813^{*}$ & ------------ & $-8.718485^{*}$ & ------------- \\
\hline CPI & -2.647964 & $-9.353815^{*}$ & $-6.422432 *$ & ------------- \\
\hline M2 & 2.249475 & $-5.103356^{*}$ & 8.951014 & $-4.844547 *$ \\
\hline
\end{tabular}

Unit root tests are the way to avoid spurious regression to calculate cointegration between the independent and dependent variables and ADF and PP test are used for this purpose. Comparing observed value with critical value, ADF test shows GDP Growth is found stationary $\mathrm{I}(0)$ that shows the null hypothesis of stationary is accepted but CPI and M2 are non- stationary in level but both are significant in first difference I(1) indicate the presence of unit root. Calculated value of PP test against critical value suggest the two variables GDP Growth (GR) and CPI are stationary I(0) at level whereas the variable M2 has unit root and significant at first difference I(1).

\section{Figure 1}

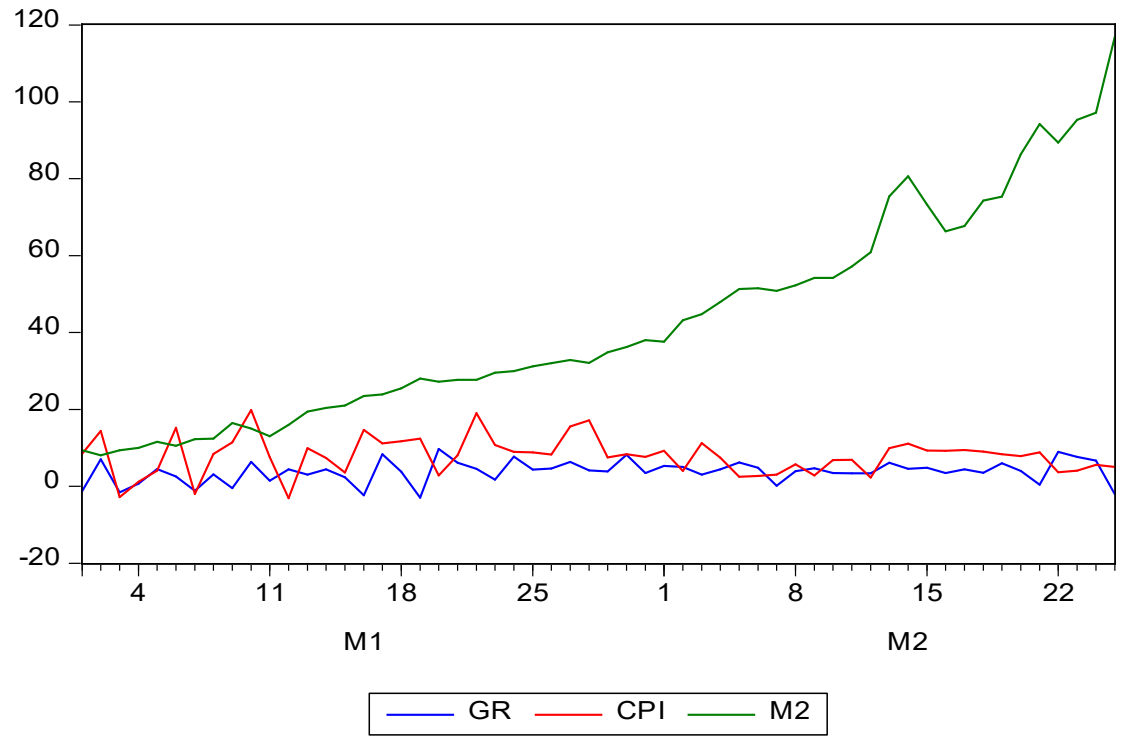


From the result of ADF and PP test some variables are found stationary at level I(0) and some are in I(1) order that suggest to apply Autoregressive Distributive Lag Model to calculate cointegration. Bounds test is suitable for this purpose and it gives the long run relationship between the variables when the variables are in I(0) and I(1) order.

\subsection{ARDL Cointegration Test}

ARDL model is selected for testing cointegration on the base of Akaike Information Criteria for optimum lag selection. The test is specified in the case that some variables in $\mathrm{I}(0)$ and some are in $\mathrm{I}(1)$ order and the following result is obtained.

\section{Table 2}

ARDL Cointegration test

Dependent Variable: D(GR)

Method: Least Squares

Date: 07/16/21 Time: 19:17

Sample (adjusted): 1/05/1965 2/25/1965

Included observations: 52 after adjustments

\begin{tabular}{crcrr}
\hline \hline Variable & Coefficient & Std. Error & t-Statistic & Prob. \\
\hline \hline C & 0.425164 & 1.361833 & 0.312200 & 0.7566 \\
D(GR(-1)) & 0.108871 & 0.309963 & 0.351240 & 0.7273 \\
D(GR(-2)) & -0.267876 & 0.230594 & -1.161675 & 0.2524 \\
D(GR(-3)) & -0.198713 & 0.140317 & -1.416171 & 0.1647 \\
D(CPI(-1)) & -0.446893 & 0.122732 & -3.641220 & 0.0008 \\
D(CPI(-2)) & -0.291210 & 0.095014 & -3.064915 & 0.0039 \\
D(CPI(-3)) & -0.244774 & 0.069856 & -3.503957 & 0.0012 \\
D(M2(-1)) & 0.068071 & 0.105955 & 0.642451 & 0.5243 \\
D(M2(-2)) & 0.005070 & 0.101282 & 0.050063 & 0.9603 \\
D(M2(-3)) & 0.117910 & 0.105821 & 1.114241 & 0.2720 \\
GR(-1) & -1.520183 & 0.354070 & -4.293455 & 0.0001 \\
CPI(-1) & 0.489892 & 0.139064 & 3.522781 & 0.0011 \\
M2(-1) & 0.034177 & 0.018111 & 1.887022 & 0.0666 \\
\hline \hline R-squared & 0.770847 & Mean dependent var & -0.053151 \\
Adjusted R-squared & 0.700338 & S.D. dependent var & 4.142544 \\
S.E. of regression & 2.267684 & Akaike info criterion & 4.687714 \\
Sum squared resid & 200.5533 & Schwarz criterion & 5.175524 \\
Log likelihood & -108.8806 & Hannan-Quinn criter. & 4.874729 \\
F-statistic & 10.93267 & Durbin-Watson stat & 2.191943 \\
Prob(F-statistic) & 0.000000 & & & \\
\hline \hline
\end{tabular}

Wald Test:

Equation: Untitled

\begin{tabular}{lccc}
\hline \hline Test Statistic & Value & $\mathrm{df}$ & Probability \\
\hline \hline F-statistic & 7.739531 & $(3,39)$ & 0.0004 \\
Chi-square & 23.21859 & 3 & 0.0000
\end{tabular}


Null Hypothesis: $\mathrm{C}(11)=\mathrm{C}(12)=\mathrm{C}(13)=0$

Null Hypothesis Summary:

\begin{tabular}{lrc}
\hline \hline Normalized Restriction $(=0)$ & Value & Std. Err. \\
\hline \hline $\mathrm{C}(11)$ & -1.520183 & 0.354070 \\
$\mathrm{C}(12)$ & 0.489892 & 0.139064 \\
$\mathrm{C}(13)$ & 0.034177 & 0.018111 \\
\hline \hline
\end{tabular}

Restrictions are linear in coefficients.

Result shows the positive impact of inflation on GDP Growth is significant in the long run. In the table F- statistics (7.739531) is obtained from ARDL Bounds test and it is compared with Pesaran critical value which is significant at $5 \%$ level. It signifies the null hypothesis that there is no long run cointegration between the variables is rejected and alternative hypothesis is accepted showing there is long run relationship between GDP Growh, inflation and broad money growth.

Table 3

Short run causality Wald test

Wald Test:

Equation: Untitled

\begin{tabular}{lccc}
\hline \hline Test Statistic & Value & df & Probability \\
\hline \hline F-statistic & 3.980610 & $(3,39)$ & 0.0144 \\
Chi-square & 11.94183 & 3 & 0.0076 \\
\hline \hline
\end{tabular}

Null Hypothesis: $C(2)=C(3)=C(4)=0$

Null Hypothesis Summary:

\begin{tabular}{lcc}
\hline \hline Normalized Restriction $(=0)$ & Value & Std. Err. \\
\hline \hline $\mathrm{C}(2)$ & 0.108871 & 0.309963 \\
$\mathrm{C}(3)$ & -0.267876 & 0.230594 \\
$\mathrm{C}(4)$ & -0.198713 & 0.140317 \\
\hline \hline
\end{tabular}

Restrictions are linear in coefficients. 
Wald Test:

Equation: Untitled

\begin{tabular}{lccc}
\hline \hline Test Statistic & Value & df & Probability \\
\hline \hline F-statistic & 5.245952 & $(3,39)$ & 0.0039 \\
Chi-square & 15.73785 & 3 & 0.0013 \\
\hline \hline
\end{tabular}

Null Hypothesis: $\mathrm{C}(5)=\mathrm{C}(6)=\mathrm{C}(7)=0$

Null Hypothesis Summary:

\begin{tabular}{lcc}
\hline \hline Normalized Restriction $(=0)$ & Value & Std. Err. \\
\hline \hline $\mathrm{C}(5)$ & -0.446893 & 0.122732 \\
$\mathrm{C}(6)$ & -0.291210 & 0.095014 \\
$\mathrm{C}(7)$ & -0.244774 & 0.069856 \\
\hline \hline
\end{tabular}

Restrictions are linear in coefficients.

Wald test conducted for short run causality is shown in the table where short run dynamic relationship is found that describes short run causality between inflation and GDP Growth at $5 \%$ level of significance.

\section{Table 4}

Error Correction Model

Dependent Variable: D(GR)

Method: Least Squares

Date: 07/16/21 Time: 19:09

Sample (adjusted): 1/06/1965 2/25/1965

Included observations: 51 after adjustments

\begin{tabular}{crcrc}
\hline \hline Variable & Coefficient & Std. Error & t-Statistic & Prob. \\
\hline \hline C & -0.129021 & 0.459365 & -0.280869 & 0.7803 \\
D(GR(-1)) & -0.671149 & 0.201278 & -3.334432 & 0.0019 \\
D(GR(-2)) & -0.699954 & 0.190251 & -3.679119 & 0.0007 \\
D(GR(-3)) & -0.270090 & 0.157880 & -1.710733 & 0.0949 \\
D(CPI(-1)) & -0.106125 & 0.075175 & -1.411706 & 0.1658 \\
D(CPI(-2)) & -0.084244 & 0.079629 & -1.057953 & 0.2964 \\
D(CPI(-3)) & -0.165403 & 0.070146 & -2.357968 & 0.0234 \\
D(M2(-1)) & 0.082563 & 0.110372 & 0.748039 & 0.4588 \\
D(M2(-2)) & -0.040674 & 0.111049 & -0.366269 & 0.7161 \\
D(M2(-3)) & 0.121555 & 0.112951 & 1.076182 & 0.2883 \\
ECT(-1) & -0.747133 & 0.246786 & -3.027448 & 0.0043 \\
\hline \hline R-squared & 0.703399 & Mean dependent var & -0.128467 \\
Adjusted R-squared & 0.629249 & S.D. dependent var & 4.147652 \\
S.E. of regression & 2.525477 & Akaike info criterion & 4.879163 \\
Sum squared resid & 255.1214 & Schwarz criterion & 5.295832 \\
Log likelihood & -113.4187 & Hannan-Quinn criter. & 5.038385 \\
F-statistic & 9.486146 & Durbin-Watson stat & 1.755975 \\
Prob(F-statistic) & 0.000000 & & & \\
\hline \hline
\end{tabular}


Table 4 shows the result of error correction model measuring the short run relationship. The coefficient of ECM is negative and significant signifies the model the speed of adjustment in long run equilibrium. The coefficient -0.7471 describes the model is rapidly changing towards long- run equilibrium by $74.71 \%$. The negative sign shows convergence in the short- run dynamic model.

\subsection{Other Tests}

\subsubsection{Serial Correlation}

Breusch-Godfrey Serial Correlation LM test is conducted to find the serial correlation in the model and the result is presented as follows:

Breusch-Godfrey Serial Correlation LM Test:

\begin{tabular}{llll}
\hline \hline F-statistic & 1.915063 & Prob. F(3,37) & 0.1441 \\
Obs*R-squared & 6.854681 & Prob. Chi-Square(3) & 0.0767 \\
\hline \hline
\end{tabular}

The test result obtained from Breusch- Goffrey test which is not significant at 5\% level suggest that no serial correlation exists in the model.

\subsubsection{Heteroskedasticity Test}

Breusch-Pegan-Godfrey test is conducted to find out the condition of Heteroskedacity in the model or not. The result obtained from the test is as follows:

Heteroskedasticity Test: Breusch-Pagan-Godfrey

\begin{tabular}{llll}
\hline \hline F-statistic & 0.813228 & Prob. F(10,40) & 0.6176 \\
Obs*R-squared & 8.616798 & Prob. Chi-Square(10) & 0.5688 \\
Scaled explained SS & 5.640984 & Prob. Chi-Square(10) & 0.8445 \\
\hline \hline
\end{tabular}

The result of the test is not significant at $5 \%$ level showing there is no Heteroskedacity in the model accepting the null hypothesis there is Homoskedacity in the given model.

\subsubsection{Stability Test}

The stability of the parameter is estimated from cumulative sum (CUSUM) and cumulative sum of square (CUSUMSQ) tests as given below. The test confirms that the model is econometrically sound and stable 


\section{Figure 2}

CUSUM Test at 5\% level of significance

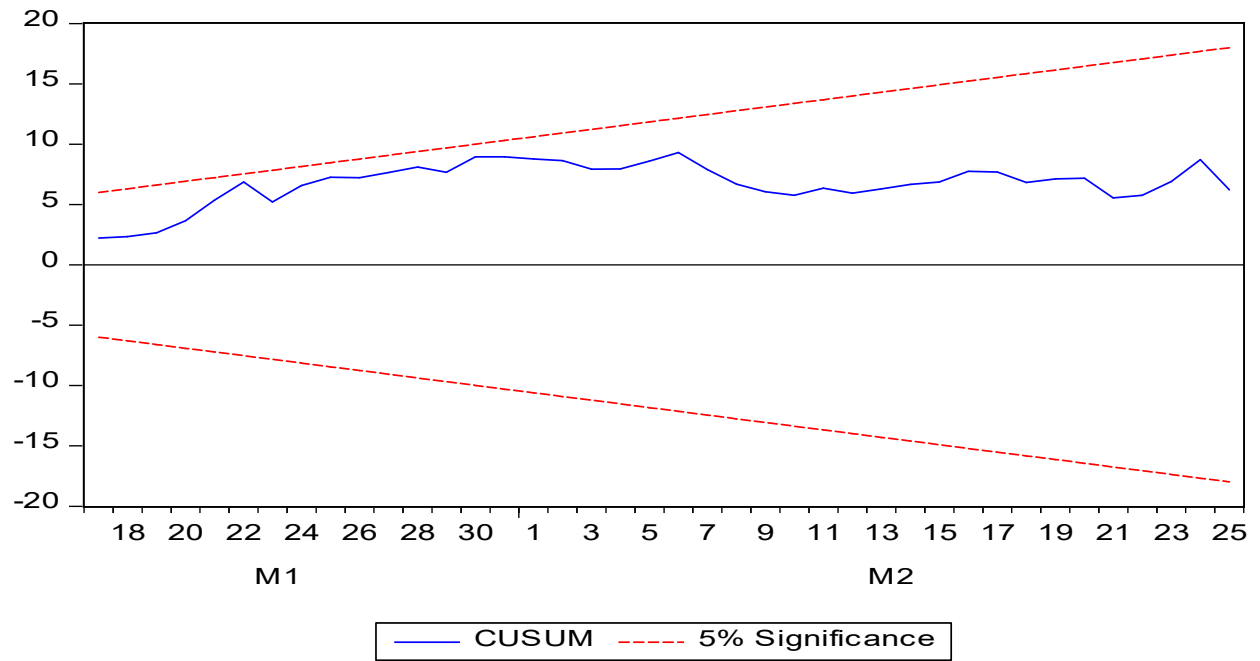

Figure 3

CUSUM of Squares Test at 5\% level of significance

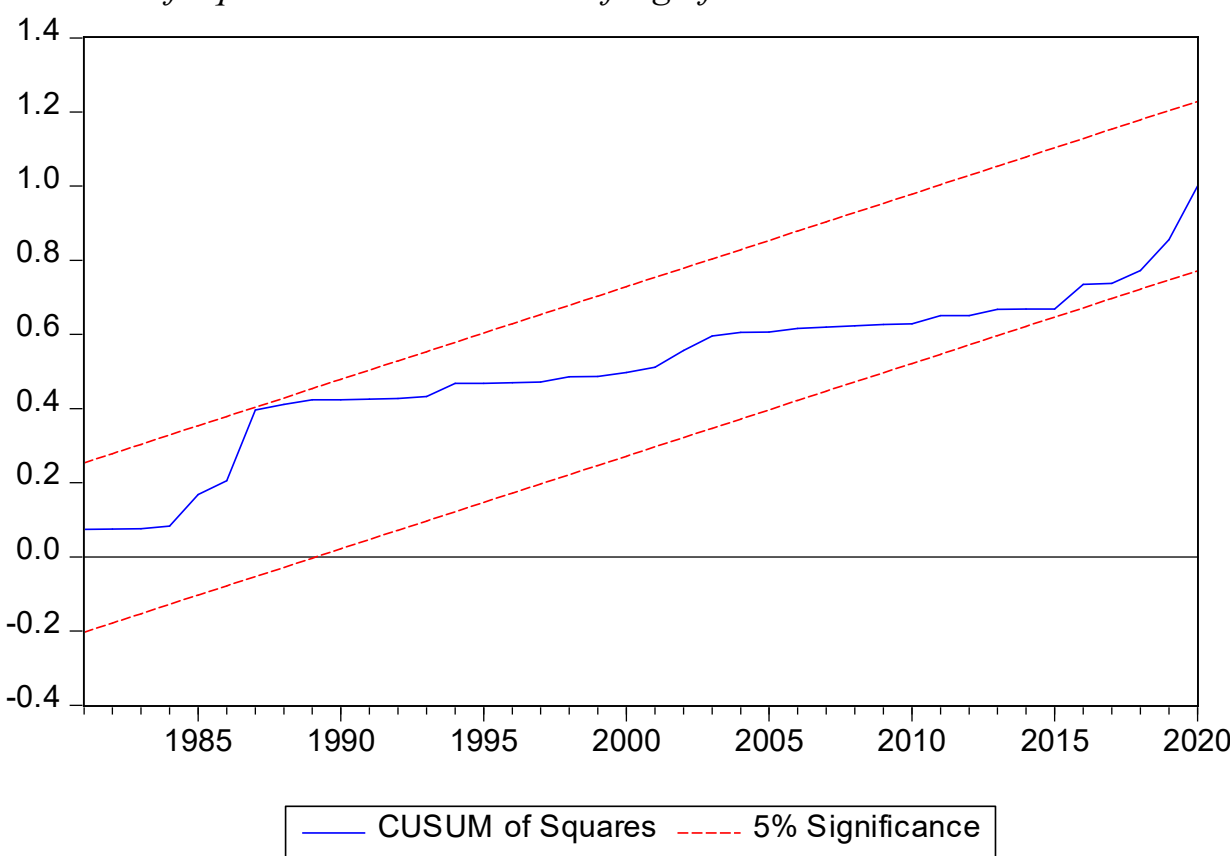

\section{CONCLUSION}

This study uses the Autoregressive Distributive Lag Model to find the impact of inflation on economic growth after ADF and Phillips- Perron unit root tests. Bounds test is applied to find the cointegration relationship and Error Correction Model that shows the speed of adjustment in the long- run equilibrium. ADF and Phillips- Perron unit root tests show some variable are in $\mathrm{I}(0)$ and some are in I(1) order so that ARDL model is specified to find the cointegration between the dependent and independent variables. 
Bounds test supports the long- run and short- run relationship between inflation and economic growth and the coefficient of error correction term is negative and significant. The ECM coefficient (-0.7471) describes the model is rapidly changing towards long- run equilibrium by $74.71 \%$. Other tests justify of having no serial correlation and heteroskedacity in the model. The model also supports for short- run causation that implies there is long- run and short impact of inflation on economic growth in Nepal. The inflation has multiple effect on economic growth where the inflation of its threshold level in Nepal is 6 percent and above this limit the inflation can hamper the economic growth (Karki et al., 2020). So inflation should be kept within its border line for the economic growth of the country by the adoption of sound monetary and fiscal policy mechanisms in the country.

\section{REFERENCES}

Adaramola, A., and, O. D.I. M., \& 2020, undefined. (2020). Impact of inflation on economic growth: evidence from Nigeria. Businessperspectives.Org, 17(2), 1-13. https://doi.org/10.21511/imfi.17(2).2020.01

Akinsola, F., \& Odhiambo, N. (2017). Inflation and economic growth: A review of the international literature. Comparative Economic Research, 20(3). https://doi.org/10.1515/cer-2017-0019

Barro, R. J. (2013). Inflation and economic growth. Annals of Economics and Finance, 14(1), 121-144. https://doi.org/10.1086/259360

Bhusal, T., Issues, S. S.-E. J. of D., \& 2011, undefined. (n.d.). Growth and inflation: Estimation of threshold point for Nepal. Nepjol.Info. Retrieved June 6, 2021, from https://www.nepjol.info/index.php/EJDI/article/view/7216

Business, R. A.-I. J. of E. and, \& 2015, undefined. (n.d.). Whether inflation hampers economic growth in Nepal. Ashwinanokha.Com. Retrieved June 6, 2021, from http://www.ashwinanokha.com/resources/2-Rajendra Adhikari.pdf

Economics, M. H.-I. J. of, and, F., \& 2015, undefined. (1961). The relationship between inflation and economic growth of Bangladesh: An empirical analysis from 1961 to 2013. Article.Ijefms.Org, 3(5), 426-434. https://doi.org/10.11648/j.ijefm.20150305.13

Hussain, S., and, S. M.-I. J. of E., \& 2011, undefined. (2011). Inflation and economic growth: Evidence from Pakistan. Researchgate.Net. https://doi.org/10.5539/ijef.v3n5p262

Jayathilake, P., \& Rathnayake, R. (2013). Testing the link between inflation and economic growth: Evidence from Asia. CThe Pakistan Development Review, 48, 863-874. http://repository.rjt.ac.lk:8080/xmlui/bitstream/handle/123456789/1312/01.pdf?sequenc $\mathrm{e}=1$

Johansen, S., and, K. J.-O. B. of E., \& 1990, undefined. (1990). Maximum likelihood estimation and inference on cointegration - with appucations to the demand for money. Digidownload.Libero.It, 52. https://digidownload.libero.it/rocco.mosconi/JohansenJuselius1990.pdf

Karki, S., Banjara, S., Agriculture, A. D.A. of, \& 2020, undefined. (n.d.). A review on impact of inflation on economic growth in Nepal. Pdfs.Semanticscholar.Org. Retrieved June 6, 
2021, from

https://pdfs.semanticscholar.org/3eaf/857650675ddcb1971b3a7ee4672c3bedc8f8.pdf

Khan, M., \& Hanif, W. (2020). Institutional quality and the relationship between inflation and economic growth. Empirical Economics, 58(2), 627-649. https://doi.org/10.1007/S00181-018-1479-7

Pesaran, M. H., Shin, Y., \& Smith, R. J. (2001). Bounds testing approaches to the analysis of level relationships. Journal of Applied Econometrics, 16(3), 289-326. https://doi.org/10.1002/JAE.616

Pollin, R., Zhu, A., \& Ha, G. (2005). Inflation and Economic Growth: A Cross-Country Nonlinear Analysis WORKINGPAPER SERIES. In elgaronline.com (Issue 413). www.umass.edu/

Research, W. M.-J. of W. E., \& 2016, undefined. (2016). Impact of inflation on economic growth in Sri Lanka. Papers.Ssrn.Com, 5(1), 1-7. https://doi.org/10.11648/j.jwer.20160501.11

Sustainable, M. A.-O. I. J. of, \& 2010, undefined. (n.d.). An empirical study on inflation and economic growth in Bangladesh. Papers.Ssrn.Com. Retrieved July 10, 2021, from https://papers.ssrn.com/sol3/papers.cfm?abstract_id=1711399

Švigir, M., pravo, J. M.-F.-F. i, \& 2017, undefined. (n.d.). Relationship between inflation and economic growth; comparative experience of Italy and Austria. Hrcak.Srce.Hr.

Retrieved July 10, 2021, from

https://hrcak.srce.hr/index.php?show=clanak\&id_clanak_jezik=285035 